Article

\title{
Disability, Access to Food and the UN CRPD: Navigating Discourses of Human Rights in the Netherlands
}

\author{
Mitzi Waltz ${ }^{1,2, *}$, Tanja Mol ${ }^{1,3}$, Elinor Gittins ${ }^{1}$ and Alice Schippers ${ }^{1,4}$ \\ ${ }^{1}$ Disability Studies in Nederland, 3811 HR Amersfoort, The Netherlands; E-Mails: m.waltz@disabilitystudies.nl (M.W.), \\ ti.mol@live.nl (T.M.), elinorgittins@gmail.com (E.G.), alice.schippers@disabilitystudies.nl (A.S.) \\ 2 Athena Institute, Vrije Universiteit Amsterdam, 1081 HV Amsterdam, The Netherlands \\ ${ }^{3}$ Amsterdam Public Health Institute, VU University Medical Center, 1081 BT Amsterdam, The Netherlands \\ ${ }^{4}$ Department of Medical Humanities, VU University Medical Center, 1081 HV Amsterdam, The Netherlands \\ * Corresponding author
}

Submitted: 13 September 2017 | Accepted: 12 January 2018 | Published: 26 March 2018

\begin{abstract}
In 2016, the Netherlands ratified the UN Convention on the Rights of Persons with Disabilities (UN CRPD), one of the last developed nations to do so. In this article, we explore how equal access to food provides a lens through which barriers to implementing a rights-based approach to disability equality can be examined in countries that are historically resistant to such discourses. Through a literature review, policy research, and interviews with disabled people, representatives of disabled people's organisations, Dutch legal scholars, food researchers, and foodbanks, we have explored barriers to equal food access in the Netherlands, and current approaches to overcoming social, economic and physical barriers. Our analysis indicates that implementation of the UN CRPD and other relevant international and EU policies continues to be limited in the Netherlands due to narrow interpretations, leading to policies and practices that do not foster equal access to resources and environments. Dutch understandings of disability equality are evolving, but encounter opposition from an entrenched system of separation and resistance to mandating change, including a reluctance to even collect data about inequality. From this basis, we identify knowledge gaps and make recommendations for steps the Netherlands could take to ensure equal access to food.
\end{abstract}

\section{Keywords}

accessibility; disability; economic rights; food; human rights; social rights

\section{Issue}

This article is part of the issue "Disability Equality: In Theory and Practice", edited by Mark Priestley (University of Leeds, UK) and Lisa Waddington (Maastricht University, The Netherlands).

(C) 2018 by the authors; licensee Cogitatio (Lisbon, Portugal). This article is licensed under a Creative Commons Attribution 4.0 International License (CC BY).

\section{Introduction}

In 2016, the authors evaluated an annual campaign to improve disability access in the Netherlands, the Week van de Toegankelijkheid ('Accessibility Week'). The campaign was sponsored by leder(in), a network of Dutch disability groups. Every year the week has a theme, and in 2016 it was access to dining out and eating together. Our evaluation began with a literature review. We found ample literature related to the primary issue of access to cafés and restaurants, ranging from reports written by Disabled Peoples' Organisations (DPOs, for example, GehandicaptenPlatform Venray, 2014) to the Dutch building code's accessibility rules for restaurants and other public spaces (Koninkrijk der Nederlanden, 2012). We conducted 16 semi-structured interviews with leaders and members of disability groups and disabled people, who helped us identify issues to explore further.

While leder(in)'s 2016 campaign concentrated on dining out, we had concerns that for many disabled peo- 
ple in the Netherlands, there were problems with access to food that went beyond physical access to restaurants. We therefore decided to look at access to food more broadly and at a deeper level. Our methodology included an additional 25 semi-structured interviews with disabled people, members and leaders of DPOs, and policymakers; additional brief informal interviews; and observations, including visits to eating establishments with DPOs.

We began by interviewing people who were part of groups involved in the leder(in) network and its original accessibility project, deliberately choosing to speak to people with a broad cross-section of physical and intellectual/developmental disabilities, from rural, suburban and urban areas. To this base we added contacts suggested by initial interviewees, and then sought out people with disabilities and members of DPOs who were not part of the leder(in) network but could offer perspectives from disabled people who had not previously been represented in the first or second sample, such as people with autism and young disabled activists. We also sought interviews with Dutch academics who were actively researching the right to food and food banks, and national and regional policymakers, to gain a systemic view. Finally, we conducted interviews with food-related service providers to learn more about their practices regarding food provision and people with disabilities.

We did face some limitations based on the sample available. Because we began the research as part of a project run by a network of DPOs and disability service organisations, the people with disabilities interviewed tended to be those who were members of DPOs. These ranged from small local groups to large national advocacy organisations, but the views and experiences of these individuals may not be representative of all Dutch people with disabilities. In particular, very few of our respondents resided in supported living or institutional care.

\section{Literature Review}

Access to adequate food is necessary for human survival. It has therefore been enshrined in international policies as a human rights issue, particularly in Article 25 of the Universal Declaration of Human Rights and Article 11 of the International Covenant on Economic, Social and Cultural Rights (ICESCR; Hospes \& van der Meulen, 2009). The right to adequate food is also recognised in the food security guidelines of the UN Food and Agriculture Organisation (FAO Council, 2004); Article 28 of the UN Convention on the Rights of Persons with Disabilities (UN CRPD); Articles 11 and 12 of the UN Convention on the Elimination of All Forms of Discrimination Against Women, and Article 24 of the Convention on the Rights of the Child (Golay \& Özden, 2012); and as an "indispensable right" in the Declaration of the Rights of Indigenous Peoples (Knuth, 2009).

The constitutions of a few EU countries recognise the right to a "decent" or "adequate" standard of living, which implicitly includes access to adequate food, as a basic human right. This list currently includes the Czech Republic, Romania, Germany and the Netherlands. The right to the means to live a "dignified" life, also implicitly including access to adequate food, is recognised in Belgium, Finland and Malta (Knuth \& Vidar, 2011). Access to food and food security issues are increasingly on the European Union's agenda as well, although pronouncements are typically geared towards the EU's role in alleviating famine and malnutrition outside Europe (for example, European Commission, 2013). The right to food is indirectly supported by Article 4(1) and other sections of the European Social Charter (Just Fair, 2014). Most recently, the "right to adequate minimum income benefits ensuring a life in dignity at all stages of life, and effective access to enabling goods and services," implicitly including adequate food, has been included in the European Pillar of Social Rights (European Parliament, Council of the European Union, \& European Commission, 2017, p. 20), which further states that "people with disabilities have the right to income support that ensures living in dignity" (p. 21).

Worldwide, people with disabilities are more likely than people without disabilities to encounter barriers to adequate food (Conference of States Parties to the Convention on the Rights of Persons with Disabilities, 2015). The quantity and quality of food that disabled people can access may be limited by these barriers, even in developed Western countries (Webber, Sobal, \& Dollahite, 2007). Inadequate access to food can also produce disability through the long-term effects of malnutrition, or exacerbate existing disability (Groce et al., 2014). Access barriers include physical barriers, attitudinal barriers, differential treatment, and inadequate information (de Jong et al., 2013). Impaired capacity, lack of support to prepare food or eat, lack of adequate income, lack of transportation or other help to obtain food, being unable to enter and use public eating establishments, or feeling unwelcome in public situations involving food (cafés, restaurants, public celebrations and events) can impact access (Webber et al., 2007).

Traditionally, the food needs of people with disabilities in the Netherlands have been addressed through state income-transfer programmes or charities. However, in July 2016 the Netherlands ratified the UN CRPD, marking a first step towards a rights-based approach to disability equality, which is predicated on seeing people with disabilities as active members of society who are empowered to claim the same rights as others rather than a socially protected class dependent on medical or charity support (Kayess \& French, 2008).

\subsection{Access to Food for Disabled People in Developed Countries}

It is clear that having a disability often impacts access to food, including in developed countries. However, we found almost no research on whether the Netherlands is 
an exception to this rule, despite court rulings that have claimed this is the case (Hospes \& van der Meulen, 2009).

The experiences of disabled people in other developed countries, such as the United Kingdom and Canada, indicate that food poverty is a significant issue for disabled people (e.g., Vozoris \& Tarasuk, 2003). For example, in the UK, people with long-term illnesses or disabilities form the largest group of individuals who require help from foodbanks to survive (New Economic Models in the Digital Economy Group, University of Hull, \& The Trussell Trust, 2016). Malnutrition is believed to affect at least three million people in the UK: residents of care homes and people with an intellectual disability are highrisk groups (Andalo, 2014). There have even been cases of British disabled people dying in circumstances where malnutrition was a factor or perhaps even the cause (for example, Gentleman, 2014), due to benefit sanctions.

People with disabilities are often reliant on state income assistance programmes. The Netherlands, like most other developed countries, has cut disability benefits in recent years and introduced increased conditionality. While concern has been raised about how this may impact disabled peoples' access to food (Hospes \& van der Meulen, 2009), we did not find any research on this topic. However, Riches and Silvasti (2014) note that food budgets are usually the only part of poor people's spending that is "elastic": housing, utilities, and healthcare costs cannot be cut by the consumer, who is then faced with dilemmas such as "heating or eating."

The EU defines food poverty as being unable to afford a meal with meat, chicken, fish or vegetarian equivalent, every second day. Across the EU, the average for food poverty among disabled people was $16.1 \%$, compared with $7.5 \%$ of non-disabled people of similar age. Amongst people aged $65+$, the average EU food poverty rate was lower: $6.8 \%$ amongst disabled seniors, though still double when compared with $3.3 \%$ of non-disabled seniors (Eurostat, 2016). However, Eurostat's statistics do not include people living in collective households or institutions. Adults living in congregate supported housing or institutional settings, and adults who cannot afford their own apartment in a country like the Netherlands, where rents are very high, will include a large number of disabled people.

For disabled people in institutional settings, food choice may be limited when group meals are served to save money, when group provision is preferred due to government or corporate policy, when food choices are limited or unhealthy, or when inadequate help is provided for residents who need assistance to eat. For example, in one study, Dutch government policy was found to push small, parent-initiated residences for adults with intellectual or developmental disabilities to serve group meals rather than to support individuals to cook for themselves (Reindl, Waltz, \& Schippers, 2016). In another, access to kitchen facilities in a large rehabilitation center for young disabled adults was curtailed in favour of residents taking meals in a café setting (Waltz,
Speelmans, \& Cardol, 2016). In the latter case, the main choices available were often fried or processed foods.

Other researchers have described so-called food deserts where access to food may be primarily via small convenience shops or fast-food outlets, with higher food costs and less healthy, nutritious food available. Webber, Sobal and Dollahite (2007) show how disability, income, and location combine to limit access to adequate food in the United States. Access to grocery shopping may also be affected by sensory or physical disabilities or sensoryperceptual issues experienced by people with autism.

Getting practical support from family and friends can be more problematic for people who are isolated from social networks. Lack of accessible transport, not being able to travel alone, and being denied access to settings were experiences that resonated with some disabled people we spoke with. For example, one young man from a small Dutch town described trying to enter a bar with friends, but being refused entry by the doorman because of his walking frame, even though a friend in a wheelchair was allowed to enter (personal communication, October 2016). Unequal treatment and discrimination can be significant barriers to access.

\subsection{Disability and Poverty}

Palmer (2011) outlines different ways of conceptualising poverty and disability and shows how the two intersect, "each a cause for and a consequence of the other" (p. 210). Palmer found no single factor responsible for poverty, but rather an interconnected web of factors, such as disability, socioeconomic status and geographical location. In high-income countries, the employment rate of people with disabilities is usually much lower than the rest of the working-age population, and for households including a person with a disability, informal caregiving becomes an additional financial cost for the household (Palmer, 2011).

Wolbring and Mackay (2014) point out that disabled people are rarely mentioned in food security news coverage in North America or the UK. They found no existing studies on media coverage of disability and food security. They also found that in Canada, most reports contained no data on disabled people experiencing food insecurity, even though some other social groups were included (Wolbring \& Mackay, 2014). Similarly, other minority groups, such as immigrants and indigenous people, were also often missing from media coverage of food security. The authors concluded: "From a disability studies perspective, increasing the visibility of the food security problems disabled people face is needed but for them to be actively involved in the discussion around food security many barriers have to be removed" (Wolbring \& Mackay, 2014, p. 22).

There is a similar knowledge gap within data collection in the Netherlands. Foodbanks collect information on age, gender, marital status, single parents, and length of foodbank use, but not disability. In 2016 Voed- 
selbanken Nederland noted that there was increased "diversity" in its client base, lumping "people with chronic illness" in with self-employed people, people with debts, and small business owners (Voedselbanken Nederland, 2016).

\subsection{Benefits and Access to Food}

Changes to benefits levels and eligibility have had a major impact on how much money disabled people in the Netherlands have to spend on food; in addition, food prices have risen at more than twice the rate of inflation: as of June 2017, 2.7\% versus 1.1\% (OECD, 2017). Foodbanks in the Amsterdam area reported in 2015 that, following a policy cutting benefits by $30 \%$ when two or more people share an address (for example, flatmates or partners), they saw a huge increase in new clients. Up to 7000 residents were said to be unable to cover their food costs anymore because of this change (AT5, 2015).

In the past two years, increases have been under $1 \%$ per year: in other words, the income of benefit recipients has decreased relative to inflation (Rijksoverheid, $2015,2016 a)$. This means that benefits have not kept up with increased costs, including both higher food prices and extra costs borne by people who have a disability, in areas like transportation, equipment and healthcare. In addition, eligibility for benefits has been increasingly tightened and made more conditional in the past two decades, especially for claimants under age 50 (Droepping, Hvinden, \& van Oorschot, 2000; OECD, 2007, 2014).

\subsection{Food Poverty in the Netherlands}

We found very little literature about food poverty in the Netherlands. A notable exception was van der Horst, Pascucci and Bol's (2014) work on the experiences of foodbank users. These authors found that the emotional impact of foodbanks is under-investigated. They argued that receivers are forced to dismiss personal food preferences and norms about how to obtain food. In addition, when the interactions are framed as charitable giving, this can cause negative emotions such as shame: "Shame is not just considered an effect of poverty, it is even being seen as one of the causes for the persistence of poverty, even across generations" (van der Horst et al., 2014 , p. 1509). They suggest further study of these human interactions in order to understand charitable giving and the emotional impact of unequal relations between giver and recipient, in order to change the relationship.

MUG, an Amsterdam-based free magazine for benefit claimants and low-wage workers, has consistently highlighted issues regarding foodbanks, including unfamiliar foods such as goose meat, vegetables removed from supermarkets due to boycotts, and expired food being given away in food packets (MUG Magazine, n.d.). Additional critical literature on the foodbank approach to food poverty includes Riches (2002), Riches and Silvasti (2014), Tarasuk and Eakin (2005) and Bol (2010).

\subsection{Legal and Policy Environment Regarding the Right to Food in the Netherlands}

Hospes and van der Meulen (2009), Wernaart (2013) and Wernaart and van der Meulen (2016) provide information about UN, EU and Dutch policy and legal frameworks regarding the right to food. These authors note that although the Netherlands has ratified many UN treaties that include access to food as a basic human right, and is also subject to similar EU laws and policies, there is no legal remedy for people whose right to food has been limited, such as asylum seekers with no right to state support and no right to work. There is an assumption, these authors say, that no one in in the Netherlands goes hungry, and that any exceptions can be diverted towards charities.

\subsection{Other Access to Food Issues in the Netherlands}

The Netherlands has a high percentage of disabled people living in various forms of institutional care compared to most other EU countries. There is a good understanding of disability-related dietary needs in many facilities (Beukers, 2013), but as noted earlier, institutions usually offer residents little or no choice about what, when or where they eat.

Research has also found a clear correlation between nutritional status and education level, with those who have no or primary education, a category that would include more disabled people than other levels, eating significantly less fruit, vegetables, and fish than those with higher levels of education (Geurts, Beukers, \& van Rossum, 2013). Although the Dutch government collects statistics on nutritional differences between ethnic groups and age groups, it does not collect statistics about the nutritional status of disabled people (Volksgezondheidenzorg, 2017).

We are aware that individual patients/clients and self-advocacy groups have lodged complaints about foodrelated issues in recent years (Stichting Geschillencommissies voor Consumentenzaken, 2017). However, we did not find research that specifically examined food choice, quality or access in Dutch institutions for disabled people.

\subsection{Accessibility of Food Information}

There is little research about people with intellectual disabilities, access to nutrition information, and support for healthy eating in the Netherlands. For people with an intellectual impairment, it can be difficult to understand and discuss health and nutrition issues (de Winter, Jansen, \& Evenhuis, 2011). Technology could be helpful, such as the online application 'MeMaatje,' which can be used to schedule exercise and healthy meals, and helps users reflect on their choices. Researchers found that $75 \%$ of users with a disability were satisfied with the app and found it user-friendly or somewhat user- 
friendly (Oostland-Sikkema \& Smit, 2014). However, in this study, caretakers noted that many users were unable to tell time and/or read texts and were therefore unable to use the application's diary feature. Caretakers also commented that confusion had arisen from images used in the application: if the foods shown were not to the taste of the users, they might resist eating the meals (Oostland-Sikkema \& Smit, 2014).

People with visual or hearing impairments can also face information barriers.

\section{Results}

\subsection{Barriers and Facilitators}

During the evaluation project, we observed many activities focused on access to eating out throughout the Netherlands. We also spoke to many individuals who dealt with the question of accessibility every day regarding their experience with local cafes and restaurants. Our respondents differentiated between physical accessibility and social accessibility. Usually, the first barriers mentioned were physical: is it possible for everyone to enter the facility? Am I able to move around freely? Is there an accessible toilet? Next, respondents typically commented on the atmosphere, including lighting and sound, and the attitude of staff towards disabled patrons. Respondents then highlighted the social experience of going out for a meal. The majority of people spoke about the quality of their company, the meal itself, the feeling of togetherness. People described positive experiences they had whilst eating out: someone offered to help them use a ramp, a waiter offered to cut their meat for them. Positive experiences were noticeably connected to social or emotional impacts. We also observed ways that establishments sought to minimise barriers to access whilst accompanying disabled people who were visiting or performing access audits on local eating establishments, including assisting people with buffets, reading menus to blind patrons, and using portable ramps to permit access to historic buildings used as restaurants.

Negative experiences, on the other hand, were mostly connected to physical barriers. Respondents offered two examples of a wheelchair-accessible toilet being promised, but not available. One turned out to be used as a storage facility, the other 'accessible' toilet was downstairs in a basement. We also observed physical barriers to access when accompanying disabled people who were performing access audits on local eating establishments. These included inaccessible toilets, buffets and bars that were too high for small people or wheelchair users to access, crowded layouts, and lack of entrance ramps.

When asked what a 'perfect' accessible restaurant would be like, almost every respondent described the same restaurants they already enjoy, but with an emphasis on the attitude of the staff. If the staff is friendly and helpful, respondents noted, barriers to access can often be overlooked or overcome.
Our interviews indicated that, while absolute food poverty was not an issue for those we spoke with, there were a number of access issues. These included access to grocery stores, cafes and restaurants, menus, and restaurant websites.

\subsection{Foodbanks and Disability in the Netherlands}

Voedselbank Nederland is a national association that sets guidelines on how foodbanks throughout the Netherlands should be run. Individual foodbanks are able to adjust these guidelines when managing their programmes. Voedselbank Nederland recommends that branches provide food parcels to an individual for up to three years; this is related to the length of the Dutch debt-relief programme. Once accepted, a recipient has the right to food parcels for six months, after which another meeting takes place to reassess their situation (personal communication, September 2016).

Voedselbank Nederland publishes data on recipients, including gender, marital status, and whether or not they have children. However, they do not keep track of how many recipients have a disability. Several local foodbanks were asked for data regarding the number of clients with a disability. All that responded explained that they also do not keep track of these figures. Four foodbanks said they were aware of distributing to several clients with a disability, whereas two responded that they were unaware of any clients with a disability (personal communications, local foodbanks and Voedselbanken Nederland, September 2016).

One foodbank responded that they know of some clients who are "mentally challenged" (personal communication, September 2016), but they were unsure of whether to describe them as disabled. An expert who has carried out research on the use of foodbanks in the Netherlands (van der Horst et al., 2014) offered possible reasons for the lack of data on disability in the Netherlands, particularly when it comes to foodbanks:

I wonder whether they may have a clear concept of what a disability would be. In my time [observing in foodbanks] I have not seen people with wheelchairs or (visibly) blind or deaf people. But one of the higher-up people I spoke to divided the population [of foodbank users] into a few bigger chunks. One of these was people who don't have the mental capacity to manage in modern society. Maybe people who don't understand the concept of credit. One example was somebody who took an advertisement for a phone literally - "zero euros" - and ended up in debt....Things such as depression or substance abuse, and how they might affect your ability to earn or manage your finances. (van der Horst, personal communication, January 2017)

Recipients with disabilities were further discussed during an in-depth interview with the intake coordinator of one 
Dutch foodbank that has been in operation since 2014. Currently, it provides parcels for around 60 recipients per month. The coordinator said they do not collect information about recipients' disability status because "we don't believe it matters" (personal communication, September 2016). They estimated that between one-fourth and onethird have a visible physical or intellectual disability. Additionally, the coordinator explained that clients are often sent to them from mental health or addiction services and other organisations; the foodbank also refers recipients to support providers as needed.

Clients with mobility impairments may struggle to travel to the distribution point or carry their parcel home. Workers at two food-parcel distribution points said they were accessible for wheelchairs and mobility scooters, and added that several clients use adapted vehicles (personal communication, September 2016). One foodbank representative said they arrange deliveries for clients who are unable to pick up their parcels due to a disability or illness (personal communication, September 2016).

An expert further noted that clients with certain disabilities might be categorised as "unworthy receivers" due to their behaviour or attendance:

The foodbank mimics the state welfare system in many ways, even though it is a private charity-it sets up rules, criteria and forms, and you need to be referred. I think there is also a concern that if receivers do not come to pick up their food, they may not actually be in need. But there are plenty of reasons why people would not pick up their parcels. One of these might be that the food provided is not good, and not worth it. Another reason might be because the receiver is suffering from depression. (van der Horst, personal communication, January 2017)

One foodbank decided not to offer a delivery service for those clients unable to come to the distribution point. Its coordinator said that some clients would be likely to rely too much on the deliveries and come to abuse the service: "you are helping people, not pampering them," she commented. She noted that many recipients were able to find creative solutions amongst themselves. Clients with a car might offer to deliver a package to someone who was temporarily unable to come to the distribution point. However, she added, "public transport here is not well connected, so people do need to cross large distances by foot or bicycle." The coordinator also noted that sometimes recipients are banned from the facility due to bad behaviour, which may or may not be due to a mental condition. In these situations, the foodbank considers the issue to be beyond its scope (personal communication, September 2016).

In discussing the contents of a typical food parcel, it became clear that the food available is often dependent on what local retailers or producers donate. Sometimes this means that products are unusual, unfamiliar or difficult to cook. The foodbank coordinator ex- plained that a local farm occasionally provides vegetables, some of which recipients complain about. This can create additional difficulties for someone with a disability, they admitted:

I can imagine if you have a rheumatic condition, and we offer you celeriac, which I happened to be preparing the other day because we had a lot of them left over, and I was thinking to myself, 'what a lot of effort goes into preparing this.' In that case, there is nothing we can do, we're not able to prepare food in this space. (personal communication, September 2016)

Food parcels often include products past or close to their expiration dates. Typical consumer behaviour contains embodied taboos around eating expired food due to potential risks; however, foodbanks require their receivers to overcome these inhibitions (van der Horst et al., 2014). In addition, the inclusion of many fatty and sugary products can have an infantilizing effect, making receivers feel they are not perceived as adults who require healthy meals (van der Horst et al., 2014).

An expert explained that the expectation of gratitude from a foodbank receiver could be especially traumatic for people with disabilities. Receivers do not want to feel that they are personally responsible for circumstances out of their control. "When it comes to a receiver with a disability, it may be that a caring approach is required, rather than a standardised approach. A young person who cannot cook can be taught to cook, but for other people, not being able to cook meals for themselves might be a static problem" (van der Horst, personal communication, January 2017).

While Voedselbank Nederland's policy states that a client should be offered a regular parcel for no more than three years, one foodbank coordinator agreed that a client might need long-term assistance, and for this reason their organisation deviates from the national guideline. They explained that several clients, some with physical or intellectual disabilities, are recognised as needing food assistance for a longer period of time, perhaps indefinitely (personal communication, September 2016). Some of these clients might not receive the extended government support they have requested, and are therefore heavily dependent on the parcel they receive from the foodbank, she noted.

\subsection{Other Food-Related Initiatives and Disability}

When disabled people face functional limitations or external barriers, cooking meals or getting to a supermarket can be problematic, restricting access to healthy food. This might be addressed by daily food delivery services. However, these services do not allow much choice, limit social interaction, and can be costly. Some communitybased projects in the Netherlands aim to improve access to food through other means. The online application 'Thuis Afgehaald' set out to connect people with ama- 
teur cooks in their neighbourhood so that they could buy and pick up home-cooked meals for an affordable price. As a branch of this service, the company set up 'Bijzonder Thuis Afgehaald' specifically for people who are not able to cook for themselves. This branch has currently connected 667 'vulnerable recipients' with home cooks (personal communication, February 2016).

The project manager of 'Bijzonder Thuis Afgehaald' explained that their service has made a difference in the eating habits of recipients. Many customers used to rely on microwave meals, sandwiches or fast food. "Research has shown that meals from our home cooks contain more fresh vegetables, pure products and little salt," she said (personal communication, February 2016). She provided the example of a home cook who prepares meals for a woman who has dementia:

This cook prepares food five days a week for this woman and passes on updates to her daughter and granddaughter who live elsewhere. In the weekend, the relatives visit this woman, and during the week she receives professional care. The relatives are very happy to count on the home cook, who enjoys being able to help. (personal communication, February 2016)

The need for this service may reflect changes in the Dutch welfare system. The project manager noted that her team often receives requests from caregivers who are looking for meals and support for their parents. Many caregivers have discovered 'Bijzonder Thuis Afgehaald' through search engines or newspapers, rather than through professional referrals. She said this was "another nice example of the shift towards informal care" (personal communication, February 2016), but one can question whether such a shift is necessarily positive, as it produces inequalities based on access to information and social contacts.

Other initiatives include 'social restaurants' (volkskeukens or 'vokos') run by community groups.

\subsection{Enforcing the Right to Food}

We found that many disabled people hoped that the Netherlands' recent ratification of the UN CRPD would bring an end to differential and problematic treatment. However, we learned from an expert on the right to food and other social and economic rights that the Netherlands has not always implemented socialeconomic rights embedded in other UN treaties that it has ratified (Wernaart, personal communication, 2016). In 2013, a National Action Plan on Human Rights was presented by the Dutch government, which acknowledged the need for a more systematic approach (Rijksoverheid, 2016b). Interestingly, this report mentioned the right to food, but only in regards to prisoners and residents of Aruba (op cit.) Legal scholars are divided on whether the Netherlands should be considered a moderately or fully monistic country. While some hold that it is moderately monistic, and therefore that constitutional implementation of international law requires parliamentary approval and official publication (for example, Alkema, 2011), the majority view is that national courts can give direct effect to international law (Vlemminx \& Meuwese, 2013). However, there is some reluctance to do so. For example, in the context of asylum seekers with neither a right to public support nor the right to work, the right to food has not been upheld in Dutch court cases. The only citation of the Netherlands' obligations regarding the right to food under UN treaties has so far been in cases regarding migrant children, with judicial rulings mentioning-but not relying on -the UN Convention on the Rights of the Child (Hospes \& van der Meulen, 2009; Wernaart \& van der Meulen, 2016). At this time, "the Dutch Courts unanimously reject direct effect of Article 11 ICESCR" as it is not seen as "binding on all persons" (Wernaart \& van der Meulen, 2016, p. 87). Dutch courts also generally do not refer to EU laws unless these have specifically been incorporated into the Dutch legal code by Parliament.

Much will therefore depend on whether the Dutch state acts to fully incorporate the provisions of the UN CRPD into national legislation and policy, thereby creating a new area of enforceable, human-rights-based law. There has been a gradual, albeit slow, move in this direction over the past 20 years. Since 2011, human rights claims can be adjudicated by the College van de Rechten van de Mens (Netherlands Institute for Human Rights). Its decisions are non-binding, but contribute to jurisprudence.

\section{Conclusion}

Our research respondents highlighted the fact that experiences involving food, such as eating out and attending community events, are crucial locations for exclusion or inclusion. Access to adequate food is an even more critical issue, due to its impact on health and wellbeing. However, interviews with disabled people, experts, policymakers and foodbank personnel substantiated that many disabled people in the Netherlands face physical, social, attitudinal and/or economic barriers when accessing food and dining experiences. The scale of the problem is unknown, however, because the state and relevant institutions involved with food policy and provision do not collect data about disabled people and access to adequate food. It is clearly problematic for the state, foodbanks and other institutions to rely on assumptions and estimates.

While we found insufficient research on disabled peoples' access to food in the Netherlands, we uncovered evidence of barriers that affected the entire spectrum of access-to-food issues across all forms of disability. As noted, many disabled people in the Netherlands hope that ratification of the UN CRPD will lead to local and national policies that establish and enforce standards on accessibility and inclusion, including social and economic 
rights. In an era of austerity budgets across Europe, this may be an uphill battle.

\section{Recommendations}

Understanding the scope of barriers to adequate food for disabled people in the Netherlands will require research that investigates current nutritional intake differences between disabled and non-disabled people, accessibility and use of information about healthy eating, choice and control over meals (especially for those in institutional care), whether disability benefits are too low to permit access to adequate food, use of emergency food provision programmes and other charitable or non-state help services by disabled people, and physical, transport and support barriers that may affect the ability of disabled people to prepare and eat meals independently and access grocery stores and eating establishments. Research should also consider the impact of intersectionality, such as differential impacts on ethnic minorities or women who have disabilities. As Neihof (2013) has noted, care and care needs are gendered, and these often determine the ability of households to manage on the budget available in order to avoid food poverty.

\section{Acknowledgements}

We would like to acknowledge the support of Disability Studies in Nederland, leder(in) and Revalidatiefonds, as well as the many experts, DPOs and disabled people who assisted us.

\section{Conflicts of Interest}

The authors declare no conflicts of interest.

\section{References}

Alkema, E. A. (2011). Netherlands. In D. Shelton (Ed.), International law and domestic legal systems: Incorporation, transformation and persuasion. Oxford: Oxford University Press.

Andalo, D. (2014, March 17). Malnutrition: It's time the UK public recognised it as a problem we face. The Guardian. Retrieved from https://www.theguardian. com/healthcare-network/2014/mar/17/malnutrition -uk-problem

AT5. (2015, July 30). Voedselbank vreest enorme toestroom nieuwe klanten. AT5. Retrieved from: http:// www.at5.nl/artikelen/144759/voedselbank_vreest_ enorme_toestroom_nieuwe_klanten

Beukers, D. (2013). Voeding en gehandicaptenzorg. Nutrinews, 2, 12-16. Retrieved from http://www. dietistvg.nl/downloads/literatuur/2013_NN_juni_ gehandicaptenzorg.pdf

Bol, W. (2010). Een voedselpakket: Mooi meegenomen? (Masters thesis). Wageningen University, Wageningen, Netherlands.
Conference of States Parties to the Convention on the Rights of Persons with Disabilities. (2015). Report of the Eighth Session. New York: United Nations. Retrieved from: http://www.un.org/disabilities/ documents/COP/cosp8_report_e.pdf

de Jong, J. M., den Exeter, A. P., \& Hulst, E. H. (2013). Economische gevolgen van ratificatie van het VN Verdrag Handicap. Rotterdam: SEOR, Universiteit van Rotterdam. Retrieved from http://www. mensenrechten.nl/sites/default/files/Eindrapportage \%20economische\%20gevolgen\%20VN\%20verdrag\% 20Handicap\%5B2\%5D.pdf

de Winter, C. F., Jansen, A. A. C., \& Evenhuis, H. M. (2011). Physical conditions and challenging behavior in people with intellectual disability: A systematic review. Journal of Intellectual Disability Research, 55(7), 675-698.

Droepping, J. A., Hvinden, B., \& van Oorschot, W.J.H. (2000). Reconstruction and reorientation: Changing disability policies in the Netherlands and Norway. European Journal of Social Security, 2(1), 35-68.

European Commission. (2013). Communication from the Commission to the European Parliament and the Council: Enhancing maternal and child nutrition in external assistance: An EU policy framework. Brussels: European Commission. Retrieved from http:// ec.europa.eu/europeaid/documents/enhancing_ma ternal-child_nutrition_in_external_assistance_en.pdf

European Parliament, Council of the European Union, \& European Commission (2017). European Pillar of Social Rights. Luxembourg: Publications Office of the European Union. Retrieved from https://ec.europa. eu/commission/sites/beta-political/files/social-sum mit-european-pillar-social-rights-booklet_en.pdf

Eurostat. (2016). Statistics explained: People at risk of poverty or social exclusion. Retrieved from http://ec. europa.eu/eurostat/statistics-explained/index.php/ People_at_risk_of_poverty_or_social_exclusion

FAO Council. (2004). Voluntary guidelines to support the progressive realization of the right to adequate food in the context of national food security. Rome: FAO Council. Retrieved from http://www.fao.org/ docrep/meeting/009/y9825e/y9825e00.htm

GehandicaptenPlatform Venray. (2014). Bereikbaarheid, toegankleijkheid, bruikbaarheid van een aantal Venrayse horeca gelegenheden. Venray: GehandicaptenPlatform Venray.

Gentleman, A. (2014, August 3). 'No one should die penniless and alone': The victims of Britain's harsh welfare sanctions. The Guardian. Retrieved from https://www.theguardian.com/society/2014/aug/03 /victims-britains-harsh-welfare-sanctions

Geurts, M., Beukers, M., \& van Rossum, C. T. M. (2013). Memo: Consumptie groenten, fruit, vis en een aantal nutriënten opgedeeld naar opleidingsniveau en verstedelijking. Bilthoven: RIVM.

Golay, C., \& Özden, M. (2012). The right to food. Geneva: Human Rights Programme of the Europe-Third World Centre (CETIM). 
Groce, N., Challenger, E., Berman-Bieler, R., Farkas, A., Yilmaz, N., Schultink, W., . . . \& Kerac, M. (2014). Malnutrition and disability: Unexplored opportunities for collaboration. Paediatrics and International Child Health, 34(4), 308-314.

Hospes, O., \& van der Meulen, B. (Eds.). (2009). Fed up with the right to food? The Netherlands' policies and practices regarding the human right to adequate food. Wageningen: Wageningen Academic Publishers.

Just Fair. (2014). Going hungry? The human right to food in the UK. London: Just Fair Consortium. Retrieved from https://www.barrowcadbury.org.uk/wp-con tent/uploads/2014/04/Going-Hungry-Human-Rightto-Food-REPORT-FINAL-1.pdf

Kayess, R., \& French, P. (2008). Out of darkness into light? Introducing the Convention on the Rights of Persons with Disabilities. Human Rights Law Review, 8(1), 1-34.

Knuth, L. (2009). The right to adequate food and indigenous peoples. Rome: FAO. Retrieved from http:// www.fao.org/docrep/016/ap552e/ap552e.pdf

Knuth, L., \& Vidar, M. (2011). Constitutional and legal protection of the right to food around the world. Rome: Food and Agriculture Organisation of the United Nations. Retrieved from http://www.fao.org/ docrep/016/ap554e/ap554e.pdf

Koninkrijk der Nederlanden. (2012). Bouwbesluit 2012. Delft: BRIS. Retrieved from http://www. bouwbesluitonline.nl

MUG Magazine. (n.d.). 'Voedsel' series. Amsterdam: Stichting ter Bevordering van de Belangen van Uitkeringsgerechtigden. Retrieved from http://www. mugweb.nl/page/4/?s=voedsel

Neihof, A. (2013). The 'facticity' of households and its significance. Wageningen: Wageningen University. Retrieved from http://edepot.wur.nl/264761

New Economic Models in the Digital Economy Group, University of Hull, \& The Trussell Trust. (2016). Mapping hunger: New technology to help tackle UK poverty. Retrieved from https://www.trusselltrust. org/wp-content/uploads/sites/2/2016/04/MappingHunger-Report.pdf

OECD. (2007). Sickness and disability schemes in the Netherlands. Paris: Organisation for Economic CoOperation and Development. Retrieved from http:// www.oecd.org/social/soc/41429917.pdf

OECD. (2014). Ageing and employment policies: Netherlands 2014: Working better with age. Paris: OECD Publishing. Retrieved from http://www.oecd-ilibrary. org/social-issues-migration-health/ageing-and-em ployment-policies-netherlands-2014_978926420815 5-en

OECD. (2017). Inflation (CPI): Netherlands. Paris: Organisation for Economic Co-Operation and Development. Retrieved from https://data.oecd.org/ price/inflation-cpi.htm

Oostland-Sikkema, A., \& Smit, K. (2014). Bruikbaarheid en effect van MeMaatje op lichaamssamenstelling en eet- en beweegpatroon bij mensen met een verstandelijke beperking (Bachelors thesis). Hanzehogeschool Groningen, Groningen, Netherlands.

Palmer, M. (2011). Disability and poverty: A conceptual review. Journal of Disability Policy Studies, 21(4), 210-218.

Reindl, M. S., Waltz, M., \& Schippers, A. (2016). Personalization, self-advocacy and inclusion: An evaluation of parent-initiated supported living schemes for people with intellectual and developmental disabilities in the Netherlands. Journal of Intellectual Disabilities, 20(2), 121-136.

Riches, G. (Ed.). (2002). First world hunger. Basingstoke: Palgrave Macmillan.

Riches, G., \& Silvasti, T. (Eds.). (2014). First world hunger revisited. Basingstoke: Palgrave Macmillan.

Rijksoverheid (2015). Uitkeringsbedragen per 1 juli 2015. Retrieved from https://www.rijksoverheid.nl/ binaries/rijksoverheid/documenten/brochures/2015 /06/29/sociale-verzekeringen-en-bijstandsuitkeringen -per-1-juli-2015/uitkeringsbedragen-per-1-juli-2015rectificatie.pdf

Rijksoverheid. (2016a). Uitkeringsbedragen per 1 juli 2016. Retrieved from https://www.rijksoverheid.nl/ documenten/publicaties/2016/06/28/uitkeringsbe dragen-per-1-juli-2016

Rijksoverheid. (2016b). Sixth periodic report: Kingdom of the Netherlands: International covenant on economic, social and cultural rights. The Hague: Rijksoverheid. Retrieved from https://www. rijksoverheid.nl/binaries/rijksoverheid/documenten/ rapporten/2016/02/01/international-covenant-oneconomic-social-and-cultural-rights/international-cov enant-on-economic-social-and-cultural-rights.pdf

Stichting Geschillencommissies voor Consumentenzaken. (2017). Geestelijk Gezondheidszorg (Klachten). Retrieved from https://www.degeschillencommissie zorg.nl/clienten/zorgcommissies/geestelijke-gezond heidszorg

Tarasuk, V. S., \& Eakin, J. M. (2005). Food assistance through 'surplus' food: Insights from an ethnographic study of food bank work. Agriculture and Human Values, 22(2), 177-186.

Van der Horst, H., Pascucci, S., \& Bol, W. (2014). The 'dark side' of food banks? Exploring emotional responses of food bank receivers in the Netherlands. British Food Journal, 116(9), 1506-1520.

Vlemminx, F. M. C., \& Meuwese, A. C. M. (2013). Commentaar op Artikel 93 van de Grondwet. In E. M. H. Hirsch Ballen G. \& Leenknegt (Eds.), Artikelsgewijs Commentaar op de Grondwet. Retrieved from https://www.nederlandrechtsstaat.nl/module/nlrs/ script/viewer.asp?soort=commentaar\&artikel=93

Voedselbanken Nederland. (2016). Feiten en cijfers Voedselbanken Nederland. Houten: Voedselbanken Nederland.

Volksgezondheidenzorg. (2017). Voeding: Cijfers \& 
context-Bevolkingsgroepen. Retrieved from https:// www.volksgezondheidenzorg.info/onderwerp/voe ding/cijfers-context/bevolkingsgroepen\#node-groen te-en-fruitconsumptie-naar-opleidingsniveau-volwas senen

Vozoris, N. T., \& Tarasuk, V. S. (2003). Household food insufficiency is associated with poorer health. Journal of Nutrition, 133(1), 120-126.

Waltz, M., Speelmans, G., \& Cardol, M. (2016). Supporting young adults on the autism spectrum towards independence: Lessons from the Netherlands. Good Autism Practice, 17(2), 5-15.

Webber, C. B., Sobal, J., \& Dollahite, J. S. (2007). Physical disabilities and food access among limited resource households. Disability Studies Quarterly, 27(3).

Wernaart, B. (2013). The enforceability of the human right to adequate food: A comparative study. Wageningen: Wageningen Academic Publishers.

Wernaart, B., \& van der Meulen, B. (2016). The right to food in international law with case studies from the Netherlands and Belgium. In G. Steier \& K. K. Patel (Eds.), International food law and policy (pp. 67-100). Cham, Switzerland: Springer.

Wolbring, G., \& Mackay, R. (2014). Analysis of newspaper coverage of food security through a disability studies lens. Journal of Sustainable Development, 7(4), 1-27.

\section{About the Authors}
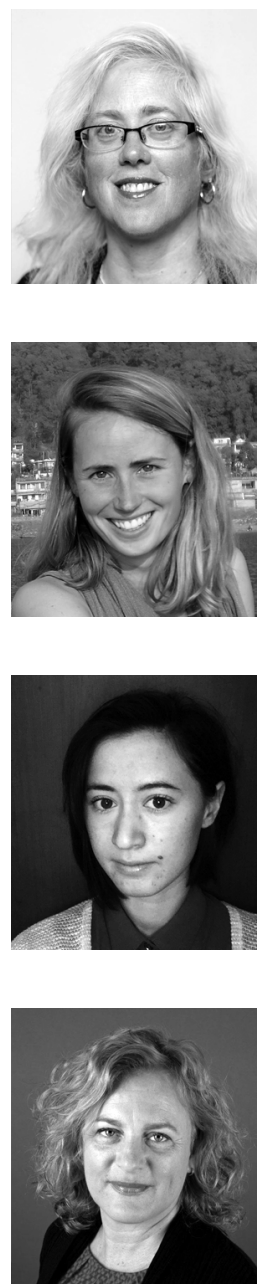

Mitzi Waltz (PhD, Media and Cultural Studies) has been involved in disability studies research on autism and housing, independent living, education and health, disability history, and disability and development. Currently Docent in Public Health at Vrije Universiteit Amsterdam and Senior Researcher with Disability Studies in Nederland, she was formerly Senior Lecturer in Autism Studies at Sheffield Hallam University, Lecturer in Autism Studies at the University of Birmingham, and Senior Lecturer in Media and Cultural Studies at the University of Sunderland.

Tanja Mol (MSc) is a nurse and qualitative researcher in public health with the Amsterdam Public Health Institute, VU University Amsterdam Medical Center. Her research interests include international public health, disability and development, inclusion, and quality of Dutch healthcare. She has published on the impact of a Community Based Rehabilitation program for children with a disability in Nepal.

Elinor Gittins graduated from the research Master's programme in Cultural Analysis at the University of Amsterdam, during which she looked at topics including surf culture, autism and the moving image. In 2016 she assisted on the national evaluation of accessibility in the Dutch hospitality sector by Disability Studies in Nederland. This experience led her to take part in further research on the topic of access to food for people with disabilities.

Alice Schippers (MSc, PhD, Interdisciplinary Social Sciences), is director of Disability Studies in the Netherlands and researcher at the Medical Humanities department at the VU University Amsterdam Medical Centre. Her research focus is on (family) Quality of Life, community development and collaborative/inclusive research. She is currently involved in projects in the Netherlands, Europe, Ethiopia and Indonesia. She is Vice President for Europe of IASSIDD and chairs its Special Interest Research Group on Quality of Life. 